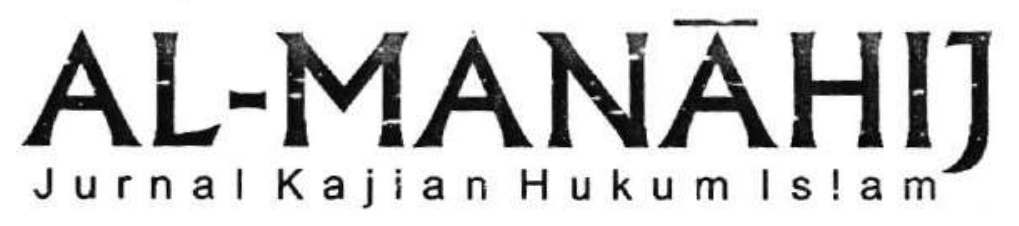




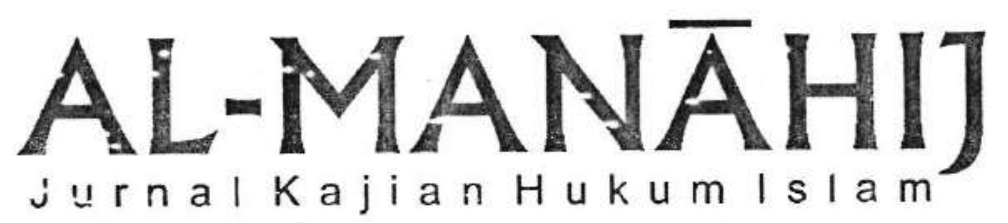

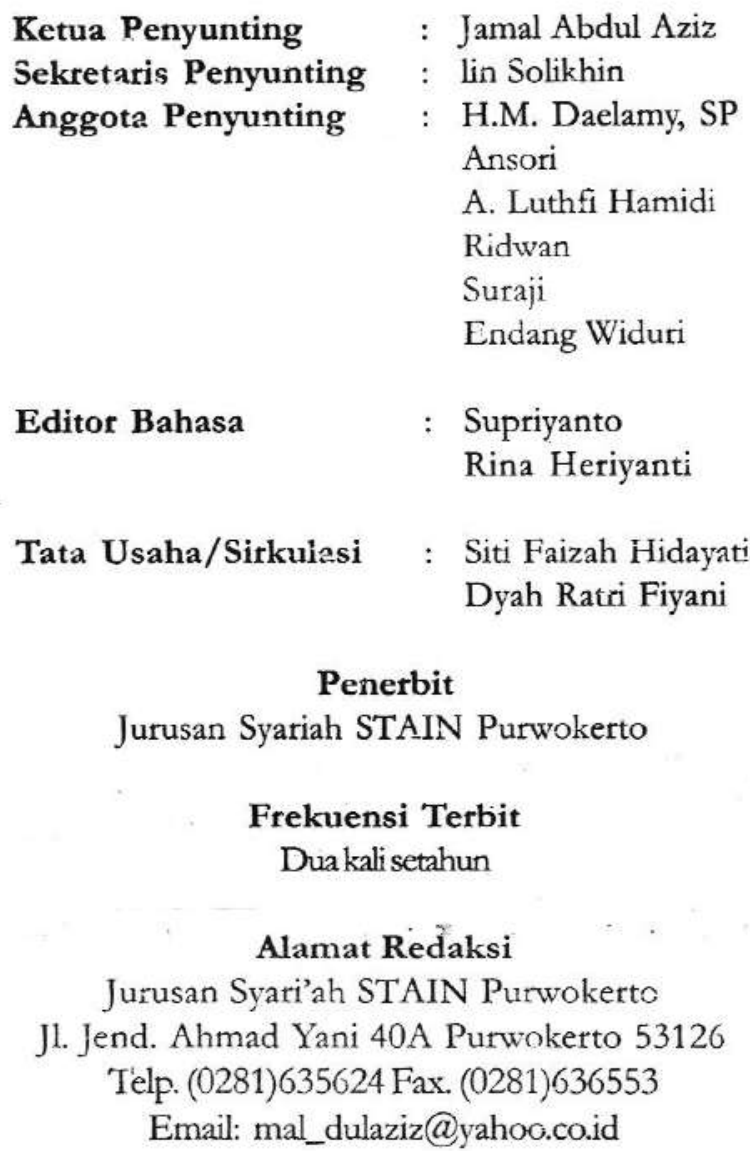

Al-Manäbij adalah jurnal ilmiah Jurusan Syariah STAIN Purwokerto yang terbit dua kali dalam setahun. Jurnal ini memfokuskan pada kajian hukum Islam dalam berbagai sudut pandang keilmuan. Redaksi mengundang para ahli dan segenap civitas akademika untuk menulis artikel sesuai dengan tema besar jurnal ini. Artikel yang dimuat tidak selalu mencerminkam pandangan redaksi ataupun institusi lain yang terkait dengan penerbitan jurnal ini. 


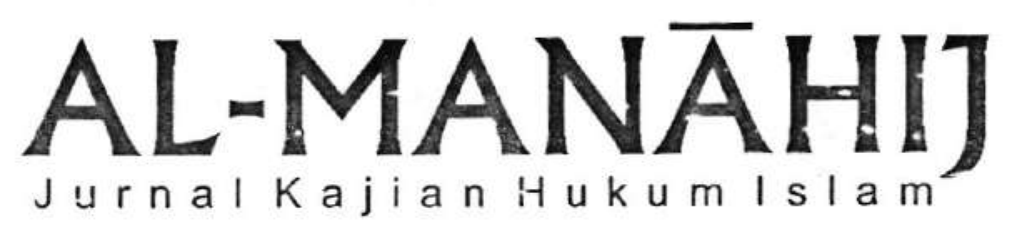

KONSEP NUSYUZ DALAM MAZHAB SYAFI'I PERSPEKTIF KEADILAN GENDER

Dwi Meitayani 1

GRASI DALAM PERSPEKTIF HUKUM ISLAM

DAN HUKUM POSITIF INDONESIA

Imdadurrouf 23

GOOD GOVERNANCE DALAM PERSPEKTIF

HUKUM ISLAM

Arief Aulia Rachman 41

PELANGGARAN HAK KEKAYAAN INTELEKTUAL

DALAM PERSPEKTIF HUKUM ISLAM

Imam Mustofa 53

PORNOGRAFI DALAM PERSPEKTIF HUKUM ISLAM

DAN HUKUM POSITIF

Vivi Aryanti 71

MENYOAL HUKUM MEROKOK

DALAM PERSPEKTIF HUKUM ISLAM

Muh. Mukri 91

MENUJU PENEGAKAN HUKUM

YANG LEBIH BERKEADILAN DAN RESPONSIF

Muh. Bachrul Ulum 113 


\title{
MENUJU PENEGAKAN HUKUM YANG LEBIH BERKEADILAN DAN RESPONSIF
}

\author{
Muh. Bacbrul Ulum*
}

\begin{abstract}
:
Law enforcement in Indonesia which still based on legal positivism model is suitable with the type of Indonesia law. The model emphasized to legal rules based on legal justice, but it failed to make substantial justice. Therefore law enforcement in Indonesia must be switched to new model of law enforcement to actualize substantial and responsive justice, because the principal function of law is attend to man not othenvise.
\end{abstract}

Kata kunci: legal positivism, responsive law, justice

\section{A. Pendahuluan}

Pasca diperdengarkannya rekaman penyadapan telepon pembicaraan antara Anggodo dengan beberapa aparat penegak hukum menggambarkan begitu mirisnya kredibilitas lembaga penegak hukum dan model penegakan hukum di Indonesia. Anggodo terdeskripsikan sedang "merekayasa" dan mengatur aparat penegak hukum agar isi Berita Acara Penyidikan (BAP) kasus hukum wakil Ketua KPK non aktif, Chandra M. Hamzah dan Bibit Samad Rianto, sesuai dengan apa yang dikehendaki. Di sisi lain terungkapnya isi rekaman tersebut tidak serta merta Kepolisian sebagai Penyidik

- Penulis adalah Magister Hukum (MH) dan Dosen tetap Jurusan Syari'ah STAIN Purwokerto. 
menetapkan Anggodo sebagai tersangka dengan alasan bukti permulaan belum cukup. Reaksi terhadap hal tersebut kemudian bermunculan, baik dari elit politik, tokoh nasional, penggiat LSM dan yang fenomental adalah gerakan satu juta face booker untuk mendukung Bibit dan Candra. Kasus tersebut menjadi bola liar realitas fenomena gunung es penegakan hukum di Indonesia, karena masih banyak kasus-kasus serupa bahkan mungkin lebih miris yang melibatkan mafia-mafia peradilan, makelar kasus (markus) atau makelar hukum (markum) atau sebutan lainnya, menggoyahkan sendi negara hukum dan mengiris rasa keadilan masyarakat.

Kasus di atas menunjukan bahwa potret penegakan hukum di Indonesia masih memiliki banyak ketimpangan baik dalam perlakuan, pelayanan maupun perlindungan di depan hukum. Tujuan hukum sebagai sarana untuk mewujudkan keadilan/kesebandingan, kepastian, ketertiban dan pengayoman hanya sekedar frase yang sulit untuk diwujudkan. Hukum sebagai norma (das sollen) dengan hukum sebagai kenyataan (das sein) tampak begitu kontras. Hukum yang seharusnya berlaku untuk semua orang justru bisa tidak berlaku bagi orang yang memiliki strata sosial, politik dan ekonomi tertentu. Hukum yang seharusnya memberikan keadilan, justru ia menciptakan ketidakadilan dan membuat jurang dengan nilai - nilai kemanusiaan. Hukum yang seharusnya memberikan proteksi malah yang terjadi adalah negoisasi dan transaksi. Hukum yang seharusnya memberi kepastian dan ketertiban, justru yang terjadi adalah ketidakpastian dan ketidaktertiban itu sendiri. Hukum yang seharusnya membawa kebaikan dan manfaat bagi setiap orang, justru ia hanya bermanfaat bagi segelintir orang saja. Hukum yang seharusnya mengayomi dan memberi rasa aman justru menjadi monster bagi pencari keadilan, bahkan hukum dipergunakan sebagai sarana untuk memperoleh, meletigimasi dan mempertahankan kekuasaan.

\section{B. Beberapa Tipe Hukum}

Penegakan hukum sangat berkaitan dengan tipe-tipe hukum yang berlaku. Nonet dan Selznick membedakan tiga klasifikasi dasar 
dari hukum dalam masyarakat, yaitu: bukum represif dimana hukum sebagai pelayan kekuasaan represif, bukum otonom dimana hukum sebagai institusi tersendiri yang mampu menjinakkan represi dan melindungi integritas dirinya, dan bukum responsif sebagai fasilitator dari berbagai respon terhadap kebutuhan dan aspirasi sosial.

Hukum Reperesif memandang keberadaan hukum semata tidak akan menjamin tegaknya keadilan, apalagi keadilan substansif, sebaliknya setiap tertib hukum memiliki potensi represif hingga batas tertentu terikat pada status quo dan dengan memberikan jubah otoritas kepada penguasa menjamin kekuasaan menjadi semakin efektif. ${ }^{1}$ Hukum represif berkembang di rezim represif dengan ditandai bahwa hukum bertujuan untuk memenuhi visi politik penguasa tanpa memperhatikan kepentingan orang yang diperintah. Pembuatan hukum tidak partisipatif karena bersal dari dan demi kepentingan penguasa. Hukum bersifat abstrak dan multi tafsir sedangkan penafsiran yang benar terletak pada penguasa. Selain itu hukum berfungsi sebagai alat legitimasi penguasa oleh karena itu seringkali terjadi proses dehumanisasi. Tipe hukum menindas (represif) adalah hukum yang mengabdi kepada kekuasaan yang represif. Tipe hukum ini praktis tanpa legitimasi sama sekali. Orang mentaatinya karena dibayang-bayangi oleh ketakutan terhadap penguasa yang keras dan kasar. Sifat represif dari hukum itu sematamata bertujuan untuk memelihara stabilitas sosial.

Sumber hukum represif yang abadi adalah tuntutan akan konformitas budaya, dimana moral yang telah disepakati kemudian diserahkan kepada negara (komunal) untuk dilakukan penegakan moral serta penanaman kesadaran untuk menginstitusionalisasi moral dan mempertahankan komunitas patuh. Hukum bergerak ke arah hukum punitif yang memasukkan sanksi ke dalam proses hukum

Dalam bentuknya yang paling jelas dan sistematis, hukum represif menunjukkan karakter-karakter berikut ini: ${ }^{2}$ hal. 33 .

${ }^{1}$ Philippe Nonet dan Philip Selznick, Huteum Responsif (Bandung: Nusamedia, 2008), ${ }^{2}$ Ibid., hal. 37 . 
1. Institusi hukum secara langsung dapat diakses oleh kekuatan politik; hukum diidentifikasikan sama dengan negara dan ditempatkan di bawah tujuan negara (raison d'etat).

2. Langgengnya sebuah otoritas merupakan urusan yang paling penting dalam administrasi hukum. Dalam "perspektif resmi" yang terbangun, manfaat dari keraguan (the benefit of the doubt) masuk ke sistem, dan kenyamanan administratif menjadi titik berat perhatian.

3. Lembaga-lembaga kontrol yang terspesialisasi, seperti polisi, menjadi pusat-pusat kekuasaan yang independen; mereka terisolasi dari konteks sosial yang berfungsi memperlunak, serta mampu menolak, otoritas politik.

4. Sebuah rezim "hukum berganda" ("dual law") me-lembagakan keadilan berdasarkan kelas dengan cara mengkonsolidasikan dan melegitimasi pola-pola subordinasi sosial.

5. Hukum pidana merefleksikan nilai-nilai yang dominan; moralisme hukum yang akan menang.

Tipe kedua, yaitu bukum otonom jelas lebih baik daripada tipe pertama karena ia mampu menjinakkan sifat represif dari kekuasaan itu demi melindungi integritas hukum itu sendiri. Tipe hukum otonom sudah memiliki legitimasi sebagai hukum. Legitimasi ini didasarkan pada gagasan bahwa stabilitas sosial itu baru memiliki keabsahan secara hukum apabila penggunaan kekuasaan diawasi menurut prinsip prinsip konstitusional, prosedur-prosedur formal, dan institusi peradilan yang bebas. Dalam fase/tipe ini lahir suatu keinginan untuk menciptakan pemerintahan berdasarkan hukum (rule of law) bukan berdasarkan orang. Karakter utama dari sistem ini adalah terbentuknya institusi - institusi hukum yang terspesialisasi dan relatif otonom yang mengklaim suatu supremasi yang memenuhi syarat dalam bidang-bidang kompetensi yang ditentukan. Karakter hukum ini diterapkan hampir di seluruh negara di dunia, termasuk di Indonesia. Karakter hukum otonom di Indonesia dicirikan dengan model negara hukum (pemerintah berdasarkan hukum/ rechtstaat/ rule of law), di 
mana ada pembagian kekuasaan lembaga tinggi negara, memproduk banyak peraturan dan sebagainya. Hukum otonom menunjukan karakter sebagai berikut: ${ }^{3}$

1. Hukum terpisah dari politik. Secara khas, sistem hukum ini menyatakan kemandirian kekuasaan peradilan, dan membuat garis tegas antara fungsi legislatif dan yudikatif.

2. Tertib hukum mendukung "model peraturan" (model of rules). Fokus pada peraturan membantu menerapkan ukuran bagi akuntabilitas para pejabat; pada waktu yang sama, ia membatasi kreativitas institusi-institusi hukum maupun risiko campur tangan lembaga-lembaga hukum itu dalam wilayah politik.

3. "Prosedur adalah jantung hukum." Keteraturan dan keadilan (fairness), dan bukannya keadilan substantif, merupakan tujuan dan kompetensi utama dari tertib hukum.

4. "Ketaatan pada hukum" dipahami sebagai kepatuhan yang sempurna terhadap peraturan-peraturan hukum positif. Kritik terhadap hukum yang berlaku harus disalurkan melalui proses politik.

Tipe kedua di atas sudah baik, namun dikhawatirkan apabila hukum hanya dijalankan secara formalitas, maka keadilan yang dicapai juga akan bersifat formal semata. Untuk itu, perlu adanya tipe hukum ketiga yang bertujuan melayani kebutuhan riil masyarakat, atau dengan perkataan lain ia lebih sebagai problem solver. Keadilan yang ingin dicapai adalah keadilan material (substantif). Nonet dan Selznick mengatakan, bahwa tipe hukum menindas tidak mungkin dapat lepas dari permasalahan "legitimasi" yang dihadapinya, kecuali ia bergerak mengubah dirinya menuju hukum otonom. Selanjutnya, tipe hukum otonom juga tidak akan mampu mengatasi problema "formalitas hukum" yang dihadapinya dan menuju ke arah tipe hukum responsif.

${ }^{3}$ Ibid ., hal. 60 . 
Model hukum ketiga menurut Nonet dan Selznick adalah bukum responsif. Hukum responsif berupaya agar membuat hukum menjadi lebih responsif terhadap kebutuhan-kebutuhan sosial dan mendorong perluasan bidang - bidang yang memiliki secara hukum. Hukum bukan entitas otonom yang terisolasi dari ilmu-ilmu dan realitas-realitas yang ada di sekelilingnya. Hukum responsif ditandai dengan kapasitas beradaptasi yang bertanggung jawab dan selektif dengan menganggap tekanan-tekanan sosial sebagai sumber pengetahuan dan kesempatan untuk melakukan koreksi diri. Hukum responsif merupakan bentuk dari realisme hukum yang responsif terhadap kebutuhan sosial, tidak sekedar mempertahankan prosedur hukum.

Hukum responsif adalah hukum yang mampu mengatasi ketegangan ketegangan akibat terjadinya perubahan sosial. Agar hukum menjadi responsif, sistem hukum dalam banyak hal hendaknya terbuka terhadap tantangan-tantangan yang ada dalam masyarakat. Sistem hukum juga harus mampu mendorong partisipasi masyarakat dan selalu sigap menyikapi setiap kepentingan yang baru muncul dalam masyarakat.

Teori bukum responsif adalah teori hukum yang memuat pandangan kritis. Teori ini berpandangan bahwa hukum merupakan cara mencapai tujuan. Hukum responsif berorientasi pada hasil dan tujuan-tujuan yang akan dicapai di luar hukum. Dalam hukum responsif, tatanan hukum dinegosiasikan, bukan dimenangkan melalui subordinasi. Ciri khas hukum responsif adalah mencari nilainilai tersirat yang terdapat dalam peraturan dan kebijakan. Model hukum responsif menyatakan ketidaksetujuan terhadap doktrin yang dianggap sebagai interpretasi yang baku dan tidak fleksibel.

Tipe hukum yang dipaparkan oleh Nonet dan Seznick, menurut Satjipto Rahardjo, sebetulnya bisa dikembalikan kepada pertentangan antara analytical jurisprudence (Legal Positivism) di satu pihak dan sociological jurisprudence di lain pihak. Analytical jurisprudence berkutat di dalam sistem hukum positif dan ini dekat dengan tipe hukum otonom pada Nonet. Aliran sociological jurisprudence maupun Nonet melalui tipe hukum responsifnya menolak otonomi hukum yang bersifat final dan tak dapat digugat. 
Analytical jurisprudence merupakan bagian dari aliran positivisme hukum. Positivisme Hukum merupakan salah satu aliran dalam filsafat (teori) hukum yang beranggapan, bahwa teori hukum itu hanya bersangkut paut dengan hukum positif saja. Hukum bercirikan rasionalistik, teknosentrik, dan universal. Positivisme Hukum sangat mengedepankan hukum sebagai pranata pengaturan yang mekanistik dan deterministik.

Hukum yang positif harus mengandung perintah, sanksi, kewajiban dan kedaulatan. Legal-positivism memandang perlu untuk memisahkan secara tegas antara hukum dan moral. Ilmu hukum tidak membahas apakah hukum positif itu baik atau buruk, dan tidak pula membahas soal efektivitasnya hukum dalam masyarakat ${ }^{4}$.

Posititivisme hukum terbagi menjadi dua yaitu : Aliran hukum positif analitis (analytical juriprudence) yang dipelopori oleh John Austin dan Aliran Hukum Murni dari Hans Kelsen. Aliran analytical juriprudence dari Austin menyatakan hukum adalah perintah dari penguasa. Hakikat hukum sendiri menurutnya terletak pada unsur "perintah" (command). Hukum dipandang sebagai suatu sistem yang tetap, logis, dan tertutup. Austin menyatakan " a lav is a command which obliges a person or person. Laws and other commands are said to proceed from superior, and to bind or oblige inferiors" ${ }^{5}$ Austin pertama-tama membedakan hukum dalam dua jenis: ${ }^{6}$

1. Hukum dari Tuhan untuk manusia (the divine laws), dan

2. Hukum yang dibuat oleh manusia, yang dibagi lagi kedalam dua bagian:

a. hukum yang sebenarnya.

b. hukum yang tidak sebenarnya.

Hukum dalam arti yang sebenarnya ini disebut juga hukum positif meliputi hukum yang dibuat oleh penguasa dan hukum yang

\footnotetext{
${ }^{4}$ Achmad Rocstandi, Responsi Filsafat Hukeum (Bandung: Armico, 1992), hal. 79.

${ }^{5}$ John Austin, The Province Of Jurisprudence, dikutip dari Darji Darmodiharjo, PoleokPokoke Filsafat Hukum (Jakarta: Gramedia, 2004), hal. 114.

${ }^{6}$ Ibid.
} 
disusun oleh manusia secara individu untuk melaksanakan hak-hak yang diberikan kepadanya. Hukum yang tidak sebenarnya adalah hukum yang tidak dibuat oleh penguasa, sehingga tidak memenuhi persyaratan sebagai hukum.

Aliran hukum positif yang analitis mengartikan hukum itu sebagai "a command of the Lawgiver" (perintah dari pembentuk Undang-undang atau penguasa), yaitu : suatu perintah dari mereka yang memegang kekuasaan tertinggi atau yang memegang kedaulatan. Undang-undang positif ditentukan secara langsung atau secara tidak langsung oleh seorang pribadi atau sekelompok orang yang berwibawa bagi seorang anggota atau anggota-anggota dari suatu masyarakat politik yang berdaulat, dalam mana pembentuk hukum adalah yang tertinggi. Dengan ketentuan ini Austin tidak menyangkal adanya norma-norma hukum Illahi, norma-norma moral dan juga hukum internasional, akan tetapi semua prinsip tersebut tidak mampu untuk meneguhkan atau meniadakan hukum yang berlaku dalam suatu negara. ${ }^{7}$ Hukum dianggap sebagai suatu sistem yang logis, tetap dan bersifat tertutup (close logical system). Hukum secara tegas dipisahkan dari moral, dari hal yang berkaitan dengan keadilan, dan tidak didasarkan atas pertimbangan atau penilaian baik buruk.

Analytical jurisprudence hanya melihat ke dalam hukum dan menyibukkan diri dengan membicarakan dan melakukan analisis ke dalam, khususnya hukum sebagai suatu bangunan peraturan yang dinilai sebagai sistematis dan logis dengan menelaah bangunan logisrasional dari deretan pasal-pasal peraturan. Dalam praktiknya sangat bertumpu pada dimensi bentuk formal dan prosedural dalam berolah hukum untuk mencapai (aksiologi) kepastian, yang benar dan adil adalah peraturan hukum itu sendiri. ${ }^{8}$

Hukum legalistik positivisme dikategorikan dalam mazhab legisme, dengan ajaran positivisme undang-undang. Hukum adalah

${ }^{7}$ Theo Huijbers, Filsafat Hukum Dalam Lintasan Sejarah (Yogyakarta: Kanisius, 1997), hal. 137-138.

${ }^{8}$ Satjipto Rahardjo, "Hukum Progresif: Hukum yang Membebaskan" dalam Jurnal Hukum Progresif, Vol. 1, No. 1 (2005), hal. 7. 
hukum undang - undang, bentuknya tertulis dan dikodifikasikan dan undang-undang ini merupakan satu-satunya sumber hukum, di luar undang-undang tidak ada sumber lain, hukum kebiasaan membentuk hukum apabila undang-undang menyebutnya ${ }^{9}$. Ruang lingkup hukum kebiasaan menjadi sempit karena menghendaki sebanyak mungkin hukum tertulis yang dianggap lebih memberikan kepastian hukum. Kalangan legisme ini begitu menjunjung tinggi hukum dengan mentasbihkan slogan yang terkemuka yaitu the rule of law. Hukum yang mengatur, menertibkan, bahkan menjadi "pemimpin" yang menentukan arah sebuah negara.

Aliran Positivisme Hukum lainnya yaitu dari Hans Kelsen, mengatakan bahwa hukum harus dibersihkan dari anasir-anasir asing non-yuridis, seperti unsur sosiologis, politis, historis, bahkan etis. Pemikirannya ini dikenal sebagai Teori Hukum Murni (the pure theory of law) ${ }^{10}$. Bagi Kelsen hukum adalah suatu sollens kategori (kategori keharusan) bukannya sein kategorie (kategori faktual). Hukum dikonstruksikan sebagai suatu keharusan yang mengatur tingkah laku manusia sebagai mahluk rasional. Dalam hal ini yang dipersoalkan oleh hukum bukalah "bagaimana hukum itu seharusnya" (what the law ought to be) melainkan "apa hukumnya" (what is the law). Dengan demikian hukum itu merupakan hukum positif an sich. Bahkan dalam ajaran hukum murni ini menolak keadilan dijadikan pembahasan dalam ilmu hukum. Bagi Hans Kelsen keadilan adalah masalah ideologi yang ideal-irasional.

Dalam paradigma positivisme definisi hukum harus melarang seluruh aturan yang mirip hukum, tetapi tidak bersifat perintah dari otoritas yang berdaulat. Kepastian hukum harus selalu dijunjung apapun akibatnya dan tidak ada alasan untuk tidak menjunjung hal tersebut, karena dalam paradigmanya hukum positif adalah satusatunya hukum. Dari sini nampak bahwa bagi kaum positivistik

' Bachsan Mustafa, Sistem Hulum Indonesia Terpadu (Bandung: Citra Aditya Bakti, 2003), hal. 37.

${ }^{10}$ Andre Ata Ujan, Pembangunan Hukum Membela Keadilan Filsafat Hukum (Yogyakarta: Kanisius, 2008), hal. 82. 
adalah kepastian hukum yang dijamin oleh penguasa. Kepastian hukum yang dimaksud adalah hukum yang resmi diperundangkan dilaksanakan dengan pasti oleh negara. Kepastian hukum berarti bahwa setiap orang dapat menuntut agar hukum dilaksanakan dan tuntutan itu pasti dipenuhi.

Berbeda dari aliran analytical jurisprudence, aliran sociological jurisprudence menganggap adanya perbedaan antara hukum positif di satu pihak dengan hukum yang hidup dimasyarakat di pihak lain. Hukum positif akan berlaku efektif apabila selaras dengan hukum yang hidup dalam masyarakat. Aliran Hukum sociological jurisprudence memandang hukum sebagai suatu lembaga kemasyarakatan yang berfungsi untuk memenuhi kebutuhan-kebutuhan sosial dan tugas dari ilmu hukum untuk mengembangkan suatu kerangka yang mana kebutuhan-kebutuhan sosial dapat terpenuhi secara maksimal. Sociological jurisprudence mengkaji bagaimana norma disesuaikan dengan rasa keadilan masyarakat sehingga ditekankan pada kesebandingan hukum dan kesadaran hukum masyarakat. Kesadaran hukum masyarakat merupakan nilai-nilai yang hidup dalam masyarakat tentang hukum, yang meliputi pengetahuan, pemahaman, penghayatan, kepatuhan atau ketaatan kepada hukum.

Teori sociological jurisprudence tumbuh dan berkembang di Amerika, yang dipelopori oleh Roscoe Pound. Sociological jurisprudence merupakan suatu teori hukum yang mempelajari pengaruh hukum terhadap masyarakat, dengan pendekatan dari hukum ke masyarakat ${ }^{11}$. Hukum menjadi instrumen untuk mengarahkan masyarakat menuju tujuan yang diinginkan, bahkan perlu menghilangkan kebiasaan masyarakat yang dipandang negatif ${ }^{12}$. Roscue Pound mengatakan hukum dapat bersifat sebagai alat untuk memperbaharui (merekayasa) masyarakat (law as a tool of social engineering). Di Indonesia konsep pound ini dikembangkan oleh Mochtar Kusumaatmadja.

"Lili Rasjidi, Filsafat Hukum: Apakab Hukum itu (Bandung: PT. Remaja Rosalakarya, 1993), hal. 49.

${ }^{12}$ Shidarta dan Darji Darmodiharjo, Pokok-Pokok Filsafat Hukum: Apa dan Bagaimana Filsafat Hukum Indonesia (Jakarta: Gramedia Pustaka Utama, 2004), hal. 197. 
Hukum dalam konsep Mochtar tidak diartikan sebagai “alat" tetapi sebagai "sarana" pembaharuan masyarakat. Pokok-pokok pikiran yang melandasi konsep tersebut adalah (1) bahwa ketertiban dan keteraturan dalam usaha pembangunan dan pembaharuan memang diinginkan, bahkan mutlak perlu, dan (2) bahwa hukum dalam arti kaedah diharapkan dapat mengarahkan kegiatan manusia ke arah yang dikehendaki oleh pembangunan dan pembaharuan itu. Untuk itu diperlukan sarana berupa peraturan hukum yang tertulis (baik perundang-undangan maupun yurisprudensi), dan hukum yang berbentuk tertulis itu harus sesuai dengan hukum yang hidup dalam masyarakat ${ }^{13}$.

Berkaitan dengan pertentangan tersebut, Satjipto Rahardjo menyatakan bahwa, Ilmu hukum yang analitis dan ilmu hukum dogmatis melakukan atomisasi dengan bekerja mereduksi kebenaran hukum yang penuh menjadi kotak-kotak dan potongan kecil. Alihalih menemukan kebenaran yang penuh, di situ kita hanya akan dihadapkan kepada skema dan skeleton hukum, bukan tampilan yang utuh. ${ }^{14}$ Untuk itu beliau menggagas hukum progresif yaitu cara berhukum yang membebaskan dari belenggu kerangkeng hukum. Hukum progresif membiarkan dirinya terbuka dan cair, sehingga selalu bisa menangkap dan mencerna perubahan yang terjadi. Tipe hukum progresif yang dikembangkan oleh Satjipto Rahardjo memiliki kemiripan dengan tipe hukum responsif Nonet dan Selznick. Tipe hukum progresif di dasari bahwa ilmu hukum tidak bisa bersifat steril dan mengisoli diri dari perubahan dunia. Ia harus mampu memberi pencerahan terhadap komunitas yang dilayani, untuk itu ilmu hukum dituntut untuk menjadi progresif. ${ }^{15}$

Ilmu hukum tidak hanya sekadar mempelajari norma-legisme (rule or regulation). Bukan juga hanya sampai pada pembahasan

${ }^{13}$ Ibid., hal. 197-199.

${ }^{14}$ Satjipto Rahardjo, "Hukum Progresif sebagai Dasar Pembangunan Ilmu Hukum Indonesia”, dalam Ahmad Gunawan BS (ed), Menggagas Hutum Progresif Indonesia (Yogyakarta: Pustaka Pelajar, 2006), hal. 13.

15 Ibid., hal. 3. 
dikotomi hukum dan masyarakat (sosiology of Lan, sosiology jurisprudence, sosio-legal). Akan tetapi, hukum juga hendaknya sampai pada intervensi ketidak-mungkinan (intervention on the impossibility), hukum menyebar ke segala penjuru (spread to all corners of the discourse), yang terakhir ini disebut sebagai deep ecoloyg ${ }^{16}$. Tranformasi eksistensi manusia yang semula berada pada sentral pengetahuan menuju ke yang "holisme". Terjadi perubahan yang fenomenal mengenai hukum "dari yang sederhana menjadi rumit" dan "dari yang terkotak-kotak menjadi satu kesatuan". Inilah yang disebutnya sebagai "pandangan holistik dalam ilmu hukum. Pandangan holistik ini memberikan kesadaran visioner bahwa sesuatu dalam tatanan tertentu memiliki bagian yang saling berkaitan baik dengan bagian lainnya atau dengan keseluruhannya

Hukum progresif menggunakan paradigma hukum untuk manusia, bukan sebaliknya manusia untuk hukum dan logika hukum, sehingga hukum progresif memedulikan faktor perilaku (bebavior, experience). Satjipto Rahardjo menyebutnya dengan slogan "berhukum dengan nurani”. Hukum harus memiliki hati nurani dikarenakan hukum itu sendiri adalah buatan manusia yang berguna untuk menyelesaikan persoalan manusia. Sehingga, sejak hukum itu adalah persoalan manusia dan bukan semata-mata persoalan peraturan, serta sejak hukum itu ada untuk manusia dan bukan sebaliknya, bukankah sebaiknya hukum itu kita biarkan mengalir saja. ${ }^{17}$ Hukum progresif berupaya menerapkan hukum agar mampu menumbuhkan ketertiban, bukan hukum yang malah menambah kekacauan, memanusiakan aturan hukum yang sangat kaku dan foralistik. Cara itu berguna agar hukum mampu mencapai kehendak tertinggi dari keinginan manusia di dunia yaitu kebahagian. Hukum berfungsi mencapat dan memberikan kebahagian kepada rakyat dan bangsanya.

${ }^{16}$ Awaludin Marwan, "Perkembangan Hukum Progresif dari Ilmu Pengetahuan Leonardo Menurut Fritjof Capra" dalam bttp:// komunitasembunpagi.blogspot.com, diakses tanggal 14 Nopember 2009.

${ }^{17}$ Satjipto Rahardjo, Biarkan Hukum Mengalir: Catatan Kritis tentang Pergulatan Manusia dan Hukum (Jakarta: Penerbit Buku Kompas, 2007), hal. 20. 
Ilmu hukum progresif adalah tipe ilmu yang selalu gelisah melakukan upaya pencarian, pembebasan dan pencerahan. Pencarian terus dilakukan, oleh karena memang hakikat ilmu adalah mencari kebenaran. Ilmu yang dipercaya oleh masyarakat untuk melakukan pencarian tersebut meskipun ia tidak mampu menggegam kebenaran sejati (ultimate trutb). Ilmu hukum progresif menghendaki agar ilmu hukum sejauh mungkin mampu menampilkan gambar hukum yang utuh dan menemukan keadilan substansif dalam hukum masyarakat. Hukum progresif juga menempatkan diri sebagai kekuatan pembebasan, yaitu membebaskan diri dari tipe berfikir normatif-positivistik, yang kaku, rutin, bermetode analitis, linier, matematis, deterministik, dan sangat submisif terhadap pengaturan yang ada. Hukum progresif melakukan proses transformasi hukum yang lebih mengutamakan tujuan dari pada prosedur, merupakan komitmen hukum progresif yang mencerahkan. Kajian hukum progresif akan terlihat bentuknya, manakala ia diberi kesempatan untuk melakukan kritik-konstruktif terhadap fenomena penegakan hukum, politik, sosial, dan budaya, maupun tentang aspek-aspek kemasyarakatan yang beragam secara nasional. Dalam kualitas dan kapasitas yang demikian maka hukum progresif memosisikan dirinya berseberangan dengan ilmu hukum analitis (recbdogmatiek, analytical jurisprudence).

Hukum Progresif menolak untuk mempertahankan status quo dalam berhukum. Mempertahankan status quo berarti menerima normativitas dan sistem yang ada tanpa ada usaha untuk melihat aneka kelemahan di dalamnya lalu bertindak mengatasi. Hampir tidak ada usaha untuk melakukan perbaikan, yang ada hanya menjalankan hukum seperti apa adanya dan secara "biasa-biasa" saja (business as usual). Pandangan status quo itu sejalan dengan cara positivistik, normatif dan legalistik. Sehingga sekali undang-undang menyatakan atau merumuskan seperti itu, kita tidak bisa berbuat banyak, kecuali hukumnya diubah terlebih dahulu. Status quo yang dipertahankan lewat asas kepastian hukum tidak hanya membekukan hukum, tetapi juga berpotensi besar membekukan masyarakat. 


\section{Penegakan Hukum yang Lebih Berkeadilan dan Responsif}

Penegakan hukum tidak pernah berproses dalam ruang hampa, tetapi selalu berkorelasi dengan variabel-variabel lain seperti sistem hukum, ideologi/tipe hukum, budaya dan karakter hukum serta entitas-entitas lain di luar hukum seperti kondisi sosial, politik, ekonomi dan budaya. Model penegakan hukum di Indonesia masih sangat dominan terpengaruh oleh tipe hukum legalistik positivisme (tipe hukum represif dan hukum otonom menurut Nonet dan Selznick) dengan sistem rule of law. Selain kasus hukum Bibit dan Candra, model legalistik positvisme sangat tergambar dalam kasus Minah yang di hukum karena mencuri 3 buah biji Kakao di Perkebunan Rumpun Sari Antan, Darma kradenan Ajibarang Banyumas, atau kasus tuduhan pencurian listrik yang menimpa Aguswandi Tanjung, penghuni apartemen ITC Roxy Mas, karena men-charge ponselnya di ruang publik apartemen, yang sebelumnya berseteru dengan pengelola karena menolak kenaikan service charge yang tidak dinegosiasikan dengan penghuni, bahkan penyidik kepolisian melakukan upaya paksa penahanan. Kasus di atas menunjukan penegak hukum hanya berpedoman kepada norma dengan telah dipenuhinya unsur perbuatan pidana tanpa memperhatikan latar belakang perbuatan tersebut dan rasa keadilan masyarakat.

Kasus tersebut menggambarkan bagaimana praksis hukum menjadi praksis yang lebih sibuk mengoperasikan skema-skema hukum yang harus rule dan logic dari pada bertanya apakah fungsi hukum dalam masyarakat sudah berjalan dengan baik. Apabila itu terjadi, sesungguhnya kita sudah terjebak ke dalam paham "manusia untuk hukum", dan bila aparat penegak hukum berpegang pada keyakinan bahwa manusia untuk hukum, maka manusia itu akan selalu diusahakan atau mungkin juga dipaksakan untuk bisa masuk ke dalam skema-skema yang telah dibuat oleh hukum.

Hukum tidak hanya rules dan logic, tetapi juga ada logika-logika yang lain. Dalam penegakan hukum, memberlakukan jurisprudence 
saja tidak cukup, tetapi harus diperkaya dengan ilmu-ilmu sosial. Dan ini merupakan tantangan bagi seluruh pihak yang terlibat dalam proses penegakan hukum, mulai dari polisi, jaksa, hakim, dan advokat untuk bisa membebaskan diri dari kungkungan hukum murni yang kaku dan analitis. Keadilan tidak bisa secara langsung ditemukan lewat proses logis dan formal. Keadilan justru diperoleh lewat institusi, karenanya, argument-argumen logis formal dicari sesudah keadilan ditemukan untuk membingkai secara yuridis formal keputusan yang diyakini adil tersebut. Oleh karena itu hukum tidak mengabdi bagi dirinya sendiri, melainkan untuk tujuan yang berada di luar dirinya.

Satjipto Raharjdo menyebut bahwa praksis penegakan hukum ternyata hanya sebatas "mengeja undang-undang, dari pada menemukan hukum di dalam undang-undang", atau seperti yang dikatakan ahli hukum Paul Scholten sebagaimana yang dikutip oleh Sudikno Mertokusumo, bahwa hukum memang ada di dalam undang-undang, tetapi hukum harus masih ditemukan dalam prakteknya. Hukum merupakan sistem terbuka karena berisi peraturan-peraturan hukum yang sifatnya tidak lengkap dan tidak mungkin lengkap. ${ }^{18}$

Menemukan hukum dalam peraturan atau UU adalah menemukan makna dan nilai yang terkandung dalam peraturan dan tidak hanya membacanya secara "datar" begitu saja. Membaca peraturan secara datar adalah memecahkan masalah tanpa melihat konteks, sehingga penegakan hukum tidak menghadirkan empati, komitmen dan dedikasi. Penegak hukum melakukan penegakan hukum dengan lebih patuh kepada susunan kata dan prosedur dari pada taat kepada nilai keadilan keadilan substantif, dan prakteknya menanggalkan bahasa nurani demi mewujudkan kepastian hukum. Ahli hukum lainnya, Dworking, menyarankan agar para aparat penegak hukum memiliki ketrampilan "Moral Reading", yaitu sebuah ketrampilan pembacaan bermakna dengan menyertai pemaknaannya secara

\footnotetext{
${ }^{18}$ Sudikno Mertokusumo, Mengenal Huleum: Suatu Pengantar (Yogyakarta: Liberty, 1999), hal. 117.
} 
filsafati, seperti keadilan dan tujuan diadakannya hukum. Bismar Siregar mengatakan bahwa "Keadilan di atas hukum/peraturan/ prosedur".

Pemikiran tersebut di atas kemudian melahirkan hukum progresif. Hukum progresif lahir karena selama ini ajaran ilmu hukum positif (analytical jurisprudence) yang dipraktikkan pada realitas empirik di Indonesia tidak memuaskan. Gagasan Hukum Progresif muncul karena prihatin terhadap kualitas penegakan hukum di Indonesia terutama sejak terjadinya reformasi pada pertengah tahun 1997. Fungsi hukum untuk memecahkan persoalan kemasyarakatan secara ideal, tetapi yang dialami dan terjadi di Indonesia sangat bertolak belakang dengan cita-cita ideal tersebut ${ }^{19}$.

Penegakan hukum yang menghadirkan compassion empati, determinasi, nurani dan dedikasi terhadap kemanusiaan disebut penegakan hukum progresif. Penegakan hukum seperti ini mengikuti maksim, hukum mengabdi kepada manusia atau kemanusiaan, dan dalam prakteknya bersifat humanis. Penegakan hukum seharusnya tidak hanya di dasarkan kepada bunyi undang-undang (positivism) tetapi pada tujuan hukum itu sendiri yaitu hukum untuk manusia sehingga dapat dicapai keadilan substantif. Ilmu hukum memberikan pintu-pintu darurat bagi penegak hukum dalam mengantisipasi situasi tidak normal. Kepolisian memiliki hak diskresi dan Jaksa Agung memiliki hak untuk men-deponeering suatu perkara demi kepentingan yang lebih besar. Penegak hukum dalam melakukan pekerjaan hukum tidak hanya melakukan rule making (membuat dan menjalankan), tetapi dalam keadaan tertentu juga melakukan rule breaking untuk melakukan teroboson terhadap peraturan, doktrin dan lainlain yang dibuatnya sendiri ${ }^{20}$.

Penegakan hukum dan pemikiran hukum perlu kembali pada filosofis dasarnya, yaitu hukum untuk manusia. Manusia menjadi penentu dan titik orientasi hukum. Hukum bertugas melayani

\footnotetext{
${ }^{19}$ Rahardjo, "Hukum., hal. 35.

${ }^{20}$ Rahardjo, "Berhukum dalam Keadaan Luar Biasa," Kompas, Kamis, 19 November 2009 , hal 6.
} 
manusia, bukan sebaliknya. Oleh karena itu, hukum itu bukan merupakan institusi yang lepas dari kepentingan manusia. Mutu hukum ditentukan oleh kemampuannya untuk mengabdi pada kesejahteraan manusia. Ini menyebabkan hukum progresif menganut ideologi hukum yang pro-keadilan dan Hukum yang pro-rakyat.

Dalam logika itulah revitalisasi hukum dilakukan setiap kali. Bagi hukum progresif, proses perubahan tidak lagi berpusat pada peraturan, tetapi pada kreativitas pelaku/penegak hukum mengaktualisasikan hukum dalam ruang dan waktu yang tepat. Para penegak hukum dapat melakukan perubahan dengan melakukan pemaknaan yang kreatif terhadap peraturan yang ada, tanpa harus menunggu perubahan peraturan (changing the law). Peraturan buruk tidak harus menjadi penghalang bagi para penegak hukum untuk menghadirkan keadilan. Penegak hukum dapat melakukan interprestasi setiap kali terhadap suatu peraturan dan secara kreatif menterjemahkan hukum itu dalam formula kepentingan-kepentingan sosial yang memang harus dilayaninya.

Penegak hukum melihat hukum tidak semata dengan optik hukum, melainkan menggunakan optik "deep ecology", yaitu suatu perspektif hukum yang melibatkan semua entitas kehidupan manusia (bolistic) sebagai satu kesatuan kehidupan, bukan semata mengeja susunan kata dan mentaati prosedur. Manusia menjadi bagian dari alam, ekosistem, lingkungan yang tak dapat dipisahkan dalam memproduksi kekuatan pengetahuan manusia. Sehingga hukum pun tak sebatas pada ekistensi manusia, melainkan merambah keluar menuju eksistensi alam. Kajian ini menjadi landasan bagi kearifan berfikir, bahwa hukum bukanlah bertujuan menciptakan kepastian hukum semata atau keadilan prosedur atau "legal justice", tetapi “substantial justice". Satu hal yang perlu dipegang teguh bahwa hukum tidak boleh melepaskan diri dari fungsi utamanya yaitu melayani manusia, dan setiap kali fungsi tersebut terusik maka kita perlu melakukan sesuatu yang kreatif untuk mengatasinya.

Realitas empiris menunjukan penegakan hukum masih lekat mendasarkan pada norma atau kaidah hukum yang tidak jarang juga 
memunculkan pelbagai persoalan yang bermuara pada sulitnya mewujudkan keadilan substansial (substantial justice) bagi para pencarinya. Cara pandang penegak hukum terhadap hukum seringkali amat kaku dan normatif-prosedural (legalistik formal) dalam melakukan konkretisasi hukum. Penegak Hukum hanya menangkap apa yang disebut "keadilan hukum" (legal justice), tetapi gagal menangkap "keadilan masyarakat" (social justice). Penegak Hakum telah meninggalkan pertimbangan hukum yang berkeadilan.

Penegakan hukum bukan menuruti pemuasan prosedur dengan spirit menang kalah sehingga penegak hukum harus selalu memilih tindakan maksimal tanpa melihat konteks, dan melibatkan empati serta dedikasinya sebagai manusia yang bernurani. Penegakan hukum progresif tetaplah dalam bingkai melindungi dan mengangkat masyarakat untuk menikmati keberlakuannya hukum, yaitu kepastian, keadilan dan manfaat dari terciptanya keamanan/ketertiban. Penegak hukum tidak boleh terbelenggu pada model penegakan hukum legalistik positifisme sehinga akan kehilangan momentum dan kesempatan untuk memberikan sumbangan bagi terciptanya kehidupan dan praksis hukum yang humanis dan berkeadilan substantif.

Bola liar kasus hukum Bibit dan Candra menguak begitu buruknya sistem penegakan hukum di Indonesia. Jajak pendapat kompas $^{21}$ menunjukan terdegradasinya kepercayaan masyarakat terhadap institusi dan aparat penegak hukum dalam menciptakan kepastian hukum dan rasa keadilan serta bersikap independen dari kekuatan luar. Penegak hukum dianggap tidak memiliki kepekaan dan tidak mementingkan masyarakat, tetapi berpihak pada kepentingan penguasa dan pengusaha. Semakin terpuruknya citra penegak hukum di mata masyarakat menjadi indikasi perlunya dilakukan

${ }^{21}$ Jajak Pendapat Kompas, "Saatnya Reformasi Penegak Hukum," Kompas, Senin 16 Nopember 2009, hal. 5. Jajak pendapat ini mengambil sampel sebanyak 823 responden melalui telepon, dan menunjukan perlunya reformasi di tubuh Kepolisian, Kejaksaan, dan KPK. Bandingkan dengan hasil survey Puskaptis yang menyatakan dari 1.250 responden, $69.20 \%$ masih membutuhkan kepolisian dan menghendaki presiden tetap menegakan supremasi hukum. Lihat Kompas.com, Rabu, 18 Nopember 2009. 
pembenahan menyeluruh lembaga penegak hukum. Untuk itu perlu dilakukan reformasi dalam penegakan hukum di Indonesia, reformasi ini tidak hanya kemudian melahirkan lembaga-lembaga penegak hukum yang bersifat ad boc tetapi yang lebih mendasar pada empowering lembaga-lembaga penegak hukum yang telah ada. Cetak biru reformasi hukum dan lembaga-lembaga penegak hukum yang telah dibuat perlu dilakukan revitalsasi dan evaluasi yang komprehensif dan integral. Reformasi penegakan hukum dilakukan secara komprehensif dan integral bagi institusi maupun aparat penegak hukum berupa reformasi di bidang kelembagaan, paradigma, struktur, kultur, moral, instrumen, citra, reputasi dan profesionalisme penegak hukum. Bahkan yang tidak kalah pentung perlunya reformasi dalam hal integrasi dan hubungan antar lembaga penegak hukum, sehingga model Integrated Criminal Justice System dapat berjalan dengan optimal dan hilangnya distrust dan mistrust lembaga penegak hukum.

Reformasi penegakan hukum sangat membutuhkan peran serta masyarakat menuju penegakan hukum yang lebih berkeadilan dan responsif. Karena pilar utama dari penegakan hukum ada dalam diri masyarakat responsif, berupa kesadaran dan budaya hukum. Masyarakat responsif adalah masyarakat yang lebih tanggap terhadap tuntutan warganya dan mau mendengarkan keluhan serta keinginankeinginan warganya. Masyarakat jenis responsif ini adalah masyarakat yang dalam mengungkapkan dan menegakan nilai-nilai sosialnya, tujuan-tujuannya, kepentingan-kepentingannya tidak dilakukan dengan melalui cara paksaan akan tetapi cendrung dilakukan dengan cara penyebarluasan informasi, pengetahuan dan komonikasi dilakukan dengan cara-cara persuasif dengan memberikan dorongan, bukannya unjuk kekuasaan atau bahkan melembagakan budaya anarkis (eigenricbting).

\section{Penutup}

Penegakan hukum di Indonesia masih mendasarkan pada penegakan hukum legal posivism (analytical jurisprudence atau hukum 
represif dan hukum otonom) dalam upaya mewujudkan kepastian hukum. Penegak hukum masih mendasarkan pada ketentuan peraturan perundang-undangan dan terikat pada norma atau kaidah hukum yang berakibat pada sulitnya mewujudkan keadilan substansial (substantial justice). Cara pandang penegak hukum terhadap hukum seringkali amat kaku dan normatif-prosedural dalam melakukan konkretisasi hukum. Penegak Hukum hanya menangkap apa yang disebut "keadilan hukum" (legal justice dan procedural justice), tetapi gagal menangkap "keadilan masyarakat" (social justice).

Paradigma penegakan hukum perlu diubah kepada paradigma penegakan hukum yang lebih berkeadilan dan responsif/ progresif. Penegakan hukum yang menghadirkan compassion empati, determinasi, nurani dan dedikasi terhadap kemanusiaan disebut penegakan hukum progresif. Penegakan hukum seperti ini mengikuti maksim, hukum mengabdi kepada manusia atau kemanusiaan bukan sebaliknya, dan dalam prakteknya bersifat humanis (hukum yang bernurani). Penegakan hukum di dasarkan kepada tujuan hukum itu sendiri yaitu hukum untuk manusia sehingga dapat dicapai keadilan substantif. Penegakan hukum progresif tetaplah dalam bingkai melindungi dan mengangkat masyarakat untuk menikmati keberlakuannya hukum, yaitu kepastian, keadilan dan manfaat dari terciptanya keamanan/ ketertiban. Penegak hukum dalam melakukan pekerjaan hukum tidak hanya melakukan rule making (membuat dan menjalankan), tetapi dalam keadaan tertentu juga melakukan rule breaking untuk melakukan teroboson terhadap peraturan, doktrin dan lain-lain yang dibuatnya sendiri.

Penegakan hukum model positivisme yang memiliki corak hukum yang bersifat formalism, rasional dan bertumpu pada prosedur, tidak dapat mewujudkan keadilan substansif dan kreatifitas penegak hukum. Bahkan turut andil dalam terpuruknya citra penegak hukum di mata masyarakat. Hal ini menjadi indikasi perlunya dilakukan pembenahan menyeluruh (reformasi) lembaga dan aparat penegak hukum. Reformasi penegakan hukum di Indonesia tidak hanya kemudian melahirkan lembaga-lembaga 
penegak hukum yang bersifat ad boc tetapi yang lebih mendasar pada empowering lembaga-lembaga penegak hukum yang telah ada. Reformasi penegakan hukum dilakukan secara komprehensif dan integral bagi institusi maupun aparat penegak hukum berupa reformasi di bidang kelembagaan, paradigma, struktur, kultur, instrumen, citra, reputasi dan profesionalisme penegak hukum. Reformasi penegakan hukum sangat membutuhkan peran serta masyarakat karena pilar utama dari penegakan hukum ada dalam diri masyarakat, terutama kesadaran dan budaya hukum masyarakatnya. 


\section{DAFTAR PUSTAKA}

Darmodiharjo, Darji. Pokok-Pokok Filsafat Hukum. Jakarta: Gramedia, 2004.

Huijbers, Theo. Filsafat Hukum dalam Lintasan Sejarah. Yogyakarta: Kanisius, 1997.

Marwan, Awaludin. "Perkembangan Hukum Progresif: Dari Ilmu Pengetahuan Leonardo Menurut Fritjof Capra." komunitasembunpagi.blogspot.com, diakses tangal 14 Nopember 2009.

Mertokusumo, Sudikno. Mengenal Hukum: Suatu Pengantar, Yogyakarta: Liberty, 1999.

Mustafa, Bachsan. Sistem Hukum Indonesia Terpadu. Bandung: Citra Aditya Bakti, 2003.

Nonet, Philippe dan Philip Selznick. Hukum Responsif. Bandung: Nusamedia, 2008.

Rahardjo, Satjipto. "Hukum Progresif sebagai Dasar Pembangunan Ilmu Hukum Indonesia," dalam Ahmad Gunawan. BS (ed), Menggagas Hukum Progresif Indonesia. Yogyakarta : Pustaka Pelajar, 2006.

. "Hukum Progresif: Hukum yang Membebaskan." Dalam Jurnal Hukum Progresif, Vol. 1, No. 1 (2005).

. "Berhukum dalam Keadaan Luar Biasa." Kompas, Kamis,

19 Nopember 2009.

. Biarkan Hukum Mengalir: Catatan Kritis tentang Pergulatan Manusia dan Hukum. Jakarta: Penerbit Buku Kompas, 2007.

Rasjidi, Lili. Filsafat Hukum Apakah Hukum itu. Bandung: PT. Remaja Rosalakarya, 1993.

Roestandi, Achmad. Responsi Filsafat Hukum. Bandung: Armico, 1992 Shidarta dan Darji Darmodiharjo. Pokok-Pokok Filsafat Hukum Apa dan Bagaimana FilsafatHukum Indonesia. Jakarta : Gramedia Pustaka Utama, 2004. 